FILOZOFIA

Roč. 76, 2021, č. 1

DOI: https://doi.org/10.31577/filozofia.2021.76.1.2

\title{
PREKONÁVANIE RELATIVIZMU V SÚČASNEJ FILOZOFII HISTÓRIE ${ }^{1}$
}

EUGEN ZELEŇÁK, Katolícka univerzita v Ružomberku, Filozofická fakulta, Katedra filozofie, Ružomberok, SR

ZELEŇÁK, E.: Overcoming Relativism in Current Philosophy of History FILOZOFIA, 76, 2021, No 1, pp. 18 - 30

During the last decades, narrativism has been one of the most influential approaches in the philosophy of history. Proponents of this movement argue that historical works are not faithful descriptions of the past reality but rather original constructions or interpretations of historians. The views of narrativists have been criticized for being relativistic. For it seems that on their view historians may shape the same data using various interpretative frameworks or conceptual schemes and this leads to plurality in history. In recent years several authors, including Paul Roth and Jouni-Matti Kuukkanen, developed some of the points and conclusions of narrativism. Although these authors are inspired by narrativism, they significantly change understanding of historical works and that is why their accounts avoid relativism. The aim of this paper is to show that these authors overcome relativism. Dualism of content and form, as Donald Davidson puts it, supports conceptual relativism. Since Roth and Kuukkanen avoid this dualism in their understanding of history, they overcome conceptual relativism in current philosophy of history.

Keywords: Relativism - Conceptual relativism - Philosophy of history - Narrativism - Paul Roth - Jouni-Matti Kuukkanen

\section{Úvod}

V polovici devätnásteho storočia sa Európou prehnala revolučná vlna, ktorá neobišla ani Uhorsko. V roku 1848 aj mad'arskí revolucionári žiadali rozšírenie slobôd, ale tiež väčšiu samostatnost' Uhorska v rámci Rakúskeho cisárstva. Ked’že uhorská vláda nemala záujem dožičit' slovanským národom Uhorska nimi požadované práva, predstavitelia Slovákov sa počas tzv. Slovenského povstania v rokoch 1848 - 1849 pridali na stranu Viedne a bojovali proti Mad'arom. ${ }^{2} \mathrm{~K}$ čomu tu došlo? S určitým zjednodušením to možno formulovat' takto. Podl'a mad'arského historického naratívu bola mad'arská

\footnotetext{
${ }^{1}$ Za pripomienky k predchádzajúcej verzii d’akujem kolegom z katedry a recenzentom.

${ }^{2}$ Informácie o Slovenskom povstaní, o jeho vnímaní a rôznych interpretáciách čerpám z prác (Brubaker, Feischmidt 2012; Škvarna 2012; Udal'cov 1951).
} 
revolúcia jednou z najvýznamnejších udalostí v dejinách Mad’arska a Slovenské povstanie bolo zradou v boji za samostatnost' Uhorska. Podla slovenského národne ladeného historického výkladu tu, naopak, išlo o oprávnený zápas za rozšírenie práv a svojbytnost' Slovákov. Podl'a marxistickej interpretácie tu išlo o reakčný boj a kolaboráciu s Viedňou.

Ako by sme mali pristúpit' $\mathrm{k}$ takým rôznorodým historickým spracovaniam minulých udalostí? Mali by sme akceptovat', že existuje pluralita prác a považovat' akýkol'vek výklad za oprávnený? Ved' Mad’ari, Slováci i marxisti majú právo pozerat' sa na minulost' každý zo svojho uhla pohl'adu. Alebo by sme mali takéto relativizovanie odmietnut' a trvat' na tom, že iba jeden výklad je správny a ostatné treba odmietnut? Lenže ktoré výklady odmietneme? Sú Slováci pripravení odmietnut' vlastný „,pozitívny" výklad Slovenského povstania a prijat' mad’arský? Dokázali by Mad’ari akceptovat' slovenský naratív a vzdat' sa svojho?

Presvedčenie o existencii viacerých alternatívnych či súperiacich výkladov, teórií, rámcov, pojmových schém alebo paradigiem, spomedzi ktorých nemožno vybrat' na základe faktov, sa spája s relativizmom. Príklad so Slovenským povstaním z rokov 1848 - 1849, zdá sa, zapadá do relativistického vnímania sveta. Preto bude sotva prekvapivé, že filozofov a teoretikov histórie, ktorí podobné príklady uvádzajú a obhajujú pluralitu výkladov, zvyčajne označujú za relativistov. Týka sa to hlavne vybraných protagonistov takzvanej narativistickej filozofie histórie. Narativizmus je prúd vo filozofii histórie, ktorý určité obdobie, najmä od sedemdesiatych rokov dvadsiateho storočia, dominoval diskusiám o povahe histórie. Narativizmus dodnes inšpiruje a ovplyvňuje viacerých aktívnych filozofov histórie. Niektorí z nich však relativizmus nezastávajú. Je preto zaujímavé preskúmat', ako sa títo súčasní filozofi histórie relativistickým tendenciám vyhýbajú. Ciel’om tohto príspevku je preto ukázat', že (a ako) súčasní autori nadväzujúci na narativizmus, konkrétne Paul Roth a Jouni-Matti Kuukkanen, relativizmus prekonávajú. Prínosom textu bude práve novátorské predstavenie pozícií Rotha a Kuukkanena ako koncepcií, ktoré sa vyhýbajú pojmovému relativizmu.

V texte najskôr stručne predstavím (pojmový) relativizmus. Potom ponúknem výklad narativistickej filozofie histórie, ktorý tento prúd spojí s pojmovým relativizmom. I ked'v skutočnosti sa dá polemizovat' o tom, nakol'ko vybraný narativista zastáva relativizmus, budem predpokladat', že minimálne niektoré vyjadrenia narativistov umožnili spájat' ich s relativizmom. Na záver sa pokúsim ukázat', že dvaja autori, ktorí na kl'účové postrehy narativistov nadväzujú, sa relativizmu vyhýbajú. Hoci Roth či Kuukkanen tak explicitne nerobia, ich koncepcie vyložím ako odmietajúce (nižšie predstavený) dualizmus, a tým aj prekonávajúce pojmový relativizmus. 


\section{O (pojmovom) relativizme}

Toto stanovisko možno priblížit' na často diskutovanom Putnamovom príklade o počítaní objektov (pozri Searle 1995, 161 - 162; Boghossian 2006, 35 - 36; Marvan 2014, kap. III). ${ }^{3}$ Predstavme si svet, ktorý pozostáva z A, B a C. Človek, ktorý je zvyknutý na „bežné počítanie“, skonštatuje, že daný svet sa skladá z troch objektov: A, B a C. Naopak, zástanca mereologického počítania ${ }^{4}$ uzavrie, že svet obsahuje sedem objektov: A, B, C, AB, AC, BC a ABC. Kto má pravdu, kol'ko objektov je $v$ skutočnosti $\mathrm{v}$ danom svete? A možno vôbec vyčíslit', kol'ko je naozaj v danom svete objektov? Ak počítame bežným spôsobom, sú tam tri objekty. Ak počítame mereologicky, je tam sedem objektov. Žiadny iný objektívnejší, pravdivejší či vernejší opis sveta neexistuje. Nejestvujú fakty $\mathrm{v}$ realite, ktoré by rozhodli medzi danými spôsobmi počítania. Ostáva nám jedine na základe iných, napríklad pragmatických dôvodov či kontextu rozhodnút', či v danej situácii uprednostníme jeden alebo druhý spôsob počítania. To následne určí, kol'ko objektov identifikujeme. Podl'a tohto relativistického prístupu platí, že aj ked' sa spravidla vyjadrujeme skrátene, v podobe „V tomto svete sú tri objekty“, v skutočnosti tu tvrdíme „Podl'a nami zvoleného spôsobu počitania sú v tomto svete tri objekty“.

Kritik relativizmu Paul Boghossian po rozbore toho, čo nazýva globálnym relativizmom Richarda Rortyho, zhŕňa: „Ako [Rorty] uvádza, existuje vel’a alternatívnych schém na opis sveta, pričom o žiadnej z nich nemožno povedat', že vernejšie zachytáva to, aké sú veci v sebe a osebe, pretože neexistuje spôsob, ako sú veci v sebe a osebe“ (Boghossian 2006, 51). Ďalej Rortyho globálny relativizmus zhŕňa $\mathrm{v}$ troch bodoch. Po prvé, neexistujú žiadne absolútne fakty. Po druhé, ak aj povieme, že niečo je tak a tak, vyjadrujeme tým, že podl'a nejakej teórie je niečo tak a tak. Po tretie, existuje množstvo alternatívnych teórií, ale neexistujú fakty, ktoré by medzi nimi rozhodli (Boghossian 2006, 52). Ak sa vrátime k príkladu z úvodu, znamená to, že ak sa Slovenské povstanie z polovice devätnásteho storočia opíše ako oprávnený boj za práva Slovákov, v skutočnosti treba mat' na pamäti, že to znamená, že v rámci akceptovaného slovenského národne orientovaného výkladu sa Slovenské povstanie pokladá za oprávnený boj za práva Slovákov. A ked’že neexistuje daný spôsob, akým sa príslušné minulé udalosti odohrali, nemožno na základe faktov vyhlásit', že napríklad slovenský výklad lepšie či horšie zodpovedá minulosti ako mad’arský.

\footnotetext{
${ }^{3}$ Treba uviest', že Putnamov príklad viacerí autori odmietajú. Kritici sa totiž z rôznych dôvodov nazdávajú, že tento príklad nie je vhodnou ilustráciou pojmového relativizmu (Boghossian 2006, 37; Baghramian, Coliva 2020, 110).

${ }^{4} \mathrm{~V}$ rámci mereológie sa berú do úvahy aj aglomeráty či mereologické sumy.
} 
Vrát'me sa však ešte na chvílu k vymedzeniu relativizmu. Ako viacerí autori upozorňujú, v literatúre sa stretneme s mnohými verziami a druhmi relativizmu. Niekedy sa rozlišuje medzi lokálnym a globálnym, respektíve sa relativizmus špecifikuje na morálny, epistemický, pojmový či ontologický. Pre všetky verzie relativizmu je však typické, že ak sa nejakým objektom pripisujú nejaké vlastnosti, vždy sa pripisujú len v kontexte nejakého výkladu, rámca, teórie, schémy. Ako upozorňujú Maria Baghramian a J. Adam Carter (2018), relativisti spravidla vyhlasujú, že veci sú len relatívne, čo znamená, že „neexistuje žiaden na rámci nezávislý uhol pohl'adu, z ktorého možno určit', aká je skúmaná vec“. Podobne aj Michael Krausz uvádza, že podl’a relativizmu sa „pravda, dobro alebo krása vzt’ahujú k referenčnému rámcu a [podl'a relativizmu] neexistujú žiadne absolútne premost'ujúce štandardy na rozhodnutie medzi súperiacimi referenčnými rámcami““(Krausz 2010, 13).

$\mathrm{Na}$ základe uvedeného tak možno zdôraznit' dva závery (pojmového) relativizmu pre určitú oblast' (napr. pre oblast' morálky, fyziky či histórie). Aspoň čast' vyjadrení z danej oblasti sú relatívne, vzt’ahujú sa, respektíve ich treba vykladat' v kontexte nejakej pojmovej schémy či referenčného rámca. Navyše neexistujú absolútne (od akejkol'vek pojmovej schémy nezávislé) štandardy či fakty, na základe ktorých by sa dala $\mathrm{v}$ danej oblasti uprednostnit' jedna pojmová schéma či referenčný rámec. Pre zjednodušenie možno prvú tézu nazvat' tézou o relativite a druhú tézou o nerozhodnutelnej pluralite. Treba mat' pritom na pamäti, že relativizmus sa hlási k obom tézam, pretože keby sa niekto prihlásil iba $\mathrm{k}$ relativite a zároveň by zastával názor, že existujú objektívne kritériá na výber spomedzi konkurenčných schém (odmietol by tézu o nerozhodnutel'nej pluralite), relativistickým dôsledkom by sa vyhol.

Možno tu nejde o dokonalé vymedzenie relativizmu, avšak pre naše účely by malo postačovat'. Treba tiež zobrat' do úvahy, že relativizmus má rôzne podoby a niektoré verzie napríklad nemusia trvat' na relativite vo všetkých oblastiach (relativita sa môže týkat' morálky, ale nie fyziky), a dokonca v jednej oblasti nemusí byt' všetko považované za relatívne. Navyše ked' ide o tézu o nerozhodnutelnej pluralite, relativizmus nemusí tvrdit', že neexistuje vôbec žiadny spôsob výberu spomedzi alternatívnych rámcov. V skutočnosti si relativista môže vybrat' nejaký rámec, len to nebude na základe faktov, objektívnych dôvodov či absolútnych štandardov, ale skôr na základe iných dôvodov, napríklad subjektívnych preferencií či spoločenskej dohody. Nakoniec treba spomenút', že pod referenčným rámcom, pojmovou schémou a pod. sa môžu rozumiet' trochu iné záležitosti. Niektorí autori tu môžu pracovat' so striktným vymedzením, iní s vágnou odvolávkou. 


\section{O narativistickej filozofii histórie}

V druhej polovici dvadsiateho storočia autori ako Arthur Danto či Louis O. Mink formulovali zaujímavé myšlienky o povahe a konštruovaní historických textov, ktoré posúvali vtedy centrálnu diskusiu o historickom vysvetlení novým smerom. Po publikovaní prác d'alšieho filozofa histórie Haydena Whita začalo byt' postupne evidentné, že vo filozofii histórie dochádza $\mathrm{k}$ zásadnému posunu. Zhruba od sedemdesiatych rokov sa pozornost' viacerých autorov sústredila na skutočnost', že historici spravidla predkladajú rozprávania o minulosti, a tak sa začali analyzovat’ rôzne aspekty historických narácií. Niektorí sa zamerali na podobnosti medzi historickými prácami a prácami z oblasti umeleckej literatúry (podobné postupy, podobné jazykové prostriedky a pod.), iní sa upriamili na historické diela ako na textové, diskurzívne objekty. Začalo sa tak hovorit' o takzvanej narativistickej filozofii histórie, teda o narativizme (Ankersmit 2009b), pričom za jej hlavných predstavitel'ov sa zvyčajne pokladali Hayden White a Frank Ankersmit (Lorenz 1998).

V literatúre sa stretneme s rôznymi vymedzeniami narativizmu. ${ }^{5} \mathrm{Tu}$ uvediem charakteristiku, ktorá podl'a mojej mienky výstižne zhŕňa to najzaujímavejšie a najpodstatnejšie. Kl'účovou myšlienkou narativizmu je, že historické diela sú výsledkom určitej konštrukcie, pričom dané diela sú nejakým spôsobom o minulosti, ale rovnako tu ide o výstup určený kontextom, preferenciami historika či jazykovými možnostami. Navyše takáto tvorba diel spravidla vedie $\mathrm{k}$ pluralite prác o rovnakej téme či časti minulosti. A to je podl'a narativistov v poriadku, pretože idea jediného správneho opisu minulosti je podl'a nich chimérou.

Zoltan Simon a Jouni-Matti Kuukkanen $(2015,155)$ o narativizme písu:

Po prvé, narativizmus oprávnene posunul záujem od atomárnych výrokov o minulosti alebo textových fragmentov $\mathrm{k}$ celým historickým textom a ich črtám. Po druhé, upozornil, že tieto texty nám ponúkajú syntetizujúce pohl'ady na minulost'. Narativisti nazvali tieto syntetizujúce entity rôzne, napríklad „narácia“, „naratívna substancia“ alebo „,reprezentácia“. Po tretie, narativisti upozornili, že texty majú vlastnosti (koherencia, plnost', významy a pod.), ktoré nemajú náprotivky v samotnej minulosti a ktoré by preto mali byt' chápané ako historikove subjektívne výtvory a postuláty o minulosti.

Podl'a narativistov je teda historické dielo výslednicou minimálne dvoch vstupov. Na jednej strane je tu sama minulost', ktorú sprostredkúvajú dostupné pramene.

\footnotetext{
${ }^{5} \mathrm{~V}$ našom regióne sa tomuto prúdu, respektíve problémom diskutovaným v rámci narativistickej filozofie histórie venovali napríklad práce (Dvorský 2009, Jančovič 2010, Šuch 2010, Zeleňák 2011, Horský, Šuch 2012, Horský 2013, Černín 2019).
} 
Na druhej strane sú tu vplyvy zo strany autorov, ktorí síce vychádzajú z pramenných materiálov, zistujú dáta, avšak svoje poznatky určitým spôsobom spracúvajú. Ako lakonicky uvádza Hayden White, historické narácie sú čiastočne nájdené a čiastočne vymyslené (White 2009, 135). Tým má na mysli to, že historické diela sú o minulosti, ale sú to do vel'kej miery tiež výtvory ich autorov.

Inak povedané, podl'a narativistov majú historické diela nejakú obsahovú stránku (dáta, informácie, fakty) a nejakú formu. Príspevkom narativistov bolo zviditel’nenie hlavne formujúcej stránky, ktorá bola občas podceňovaná, či dokonca prehliadaná. Na ilustráciu tejto kl'účovej tézy narativizmu možno použit' kantovský výklad Whitovho stanoviska. Podla Whita je sama minulost' vznešená, zmysluprázdna, hodnotovo neutrálna, je to akási chaotická masa (White 2009, 137; Ankersmit 2009a, 226). Lenže túto masu historici sprostredkujú vo svojich prácach v nejakej forme. Neponúkajú totiž chaotické nakopenie informácii, ale tradične o minulých udalostiach rozprávajú príbehy. Ako je to však možné, ak sama minulost' nemá význam, nemá naratívnu podobu? Podl'a Whita naratívnu formu a zmysel historickému dielu jednoducho dodajú historici (White 2011). Detaily tohto procesu tu nie sú podstatné. Kl'účovým dôsledkom je, že ak existujú rôzni historici, s rôznymi preferenciami, rôznym vzdelaním a ovplyvnení rôznymi ideológiami, rôzni historici priblížia rovnaké historické obdobie či udalosti cez často nekompatibilné historické narácie.

Využijúc príklad o Slovenskom povstaní toto teoretické stanovisko možno ilustrovat' takto. Ked’že udalosti z daných rokov treba pokladat' za vznešené a nesformované, v samej minulosti sa neodohrali ani reakčné, ani progresívne činy, neudial sa tam ani príbeh zrady, ani príbeh oprávneného vzdoru. To až historici vo svojich dielach sformovali takéto príbehy, obdarené tým či oným významom. Ich výsledné príbehy sú pritom konštruované s využitím preferovaných schém, prístupov či paradigiem (téza o relativite). Takže historici s rôznymi preferenciami, inklináciami, pracujúci v iných pojmových schémach a pod. spravidla predkladajú odlišné práce o tých istých udalostiach. White túto pluralitu neodmieta, ale naopak, upozorňuje, že tu ide o zrejmý dôsledok jeho koncepcie, ktorú formuluje vo svojej hlavnej práci Metahistória (White 2011, 50). Ked’že neexistujú fakty, ktoré by rozhodli o tom, či sa v minulosti odohrala zrada alebo oprávnený vzdor, či je správny jeden alebo druhý výklad (téza o nerozhodnutelnej pluralite), zdá sa, že sa otvára priestor na kritiku Whita a narativistov za relativizmus.

Wulf Kansteiner vo svojej štúdii o Whitovi uvádza, že jeho dielo býva najčastejšie kritizované za formalizmus a relativizmus $(1993,294)$. Vo svojej analýze Metahistórie Whita obviňuje z relativizmu (unlimited relativism) aj Eugene O. Golob (1980, 65). Takáto kritika, samozrejme, nie je prekvapivá. Ked’že White víta pluralitu a dokonca nás presviedča, že neexistuje objektívny spôsob ako na základe faktov vybrat’ správny 
historický výklad, oponenti to považujú za propagáciu relativizmu v histórii. V skutočnosti možno jednoduchému obviňovaniu Whita $\mathrm{z}$ relativizmu do určitej miery vzdorovat', avšak v tomto texte sa takejto obrane nemusíme venovat'. V tomto kontexte je postačujúce, že narativisti na čele s Whitom vyzerajú ako relativisti a sú za relativizmus v literatúre kritizovaní. Ako je to však s ich nasledovníkmi?

\section{Paul Roth a Jouni-Matti Kuukkanen}

Paul Roth je americký filozof, ktorý v posledných desat'ročiach analyzuje epistemologické otázky histórie a formuluje originálne návrhy na uchopenie historickej práce so zámerom, aby sa vyhol tak naivnému empirizmu, ako aj radikálnemu skepticizmu. Roth je totiž presvedčený, že historické práce prinášajú poznatky a historici predkladajú zmysluplné vysvetlenia, len jeho výklad týchto vecí je špecifický (Roth 2020).

V prvom rade treba uviest', že Roth vo viacerých úvahách a analýzach nadväzuje na závery narativistov, hlavne na postrehy Arthura Danta a Louisa Minka. Inšpiruje sa napríklad Dantovým pojmom naratívnych viet (Danto 1985) a Minkovými rozbormi historickej narácie (Mink 1987; Mink 2009), z ktorých odvodzuje záver, že historické rozprávania nie sú výsledkom snahy čo najvernejšie zachytit' fixnú minulú predlohu, ale sú výsledkom konštrukčnej aktivity. Inak povedané, historici vo svojich dielach neponúkajú čo najpresnejšie reprezentácie vopred sformovanej Francúzskej revolúcie, Studenej vojny či Slovenského povstania. Historici tieto udalosti do vel'kej miery konštruujú, takže narativisti mali pravdu, ked' zdôrazňovali tvorivý aspekt historického remesla.

V prospech takéhoto konštruktivistického chápania Roth argumentuje aj takto. Konkrétna udalost' sa stáva udalost’ou vd’aka nášmu záujmu; v určitom zmysle ju konštituujú až historici v rámci ich skúmania a historických rozprávaní (Roth 2017, 404; Roth 1988; Roth 2020). Takýto názor môže vyzerat' radikálne, ale Roth tu netvrdí, že nič mimo rozprávaní neexistuje, len upozorňuje, že napríklad Slovenské povstanie nie je nejaká vopred daná a jasne ohraničená udalost', ale udalost', ktorá v istom zmysle slova „vznikla“ až vd'aka tomu, že ju začali analyzovat', opisovat', vysvetl'ovat' historici (a zrejme aj pamätníci a i.). Aktéri minulého diania, samozrejme, niečo prežili, ale keby sa v odbornej či inej diskusii nekonštituovalo Slovenské povstanie ako osobitá udalost' hodná pozornosti, nebola by v tejto podobe vlastne dodnes predmetom historických prác. Roth takýto výklad podporuje úvahami o historických naráciách, ktoré sú podl'a neho zároveň vysvetlenia. Svoju analýzu zhŕňa do troch klúčcových téz (Roth 2017, 399 - 402): 1) Udalosti sú neoddelitel'nou súčast'ou narácií, v ktorých figurujú; 2) V histórii existuje pluralita rozprá- 
vaní o rovnakom období, pretože udalosti z daného obdobia sa opisujú retrospektívne, so znalost'ou neskoršieho diania, ktoré mení naše opisy a rozprávania; 3) $\mathrm{Ne}$ existuje jeden vopred „napísaný“ fixný dejinný príbeh, ktorý by historici iba postupne dopíňali. Ako to formuluje sám autor:

„Minulost"“ nemôže existovat' ako statický objekt, o ktorom dúfame, že budeme postupne vediet' viac, podobne ako je tomu v Kuhnovej predstave o normálnej vede. Nič nepodporuje predpoklad o existencii Minulosti, ktorá by bola chápaná ako zatial' neporozprávaný, alebo iba čiastočne porozprávaný príbeh, avšak stále jeden rovnaký príbeh, l'udská minulost' prerozprávatel'ná sub specie aeternitatis (Roth 2020, 15).

Keby jednotlivé Rothove tézy mali byt' presvedčivé, určite by si vyžadovali podrobnejšiu analýzu. Pre potreby tohto príspevku je však podstatné niečo iné. Roth sa pri rozbore historickej práce nepúšt’a do úvah o formovaní beztvarej látky autorskou formou. Navrhuje, aby sme sa na historické dielo nepozerali ako na výsledok zobrazenia minulosti, ale skôr ako na výstup ovplyvňovaný faktormi z opačnej strany. Nie akási daná minulost’ určuje podobu historického diela,${ }^{6}$ ale určujúce sú faktory pôsobiace na historika a dielo zo strany vzdelania, preferovaného prístupu, prijímaného kánonu, tréningu a pod. (Roth 2012, 327 - 328). Inak povedané, marxistický historik nebude písat' o reakčnom Slovenskom povstaní preto, že na minulé udalosti (látku) aplikuje marxistickú pojmovú schému (svoju formu), ale preto, že je pod vplyvom marxistických kolegov a presvedčení, má za sebou určitú špecifickú prax a pod.

Jouni-Matti Kuukkanen je fínsky autor, ktorý pred niekol'kými rokmi predstavil víziu postnarativistickej filozofie histórie vo svojej zaujímavej knihe Postnarrativist Philosophy of Historiography (2015). Kuukkanen sa vo svojom originálnom návrhu pokúša prekonat' narativizmus, ale jeho inšpirácia a korene vychádzajú práve z tohto učenia. Autor sa otvorene hlási k takzvanému narativistickému postrehu (narrativist insight), podl'a ktorého historické práce primárne formulujú syntetizujúce pohl’ady na minulost' (Kuukkanen 2015, 1). Historici tak vo svojich prácach predkladajú akési celostné výklady, ktoré sa občas nazývajú historické narácie, naratívne substancie alebo historické reprezentácie. Podl’a Kuukkanena narativisti poukázali na dôležitú vec, ked' upozornili na to, že syntetizujúce pojmy ako renesancia, Francúzska revolúcia, studená vojna a pod. sú výtvory historikov, a nie priamočiare opisy minulosti. Tu sa však dostávame k slabine narativizmu. Podl’a Kuukkanena história je racionálna

${ }^{6} \mathrm{O}$ determinácii zo strany reality hovoria určité verzie realistického prístupu. Tomáš Marvan napríklad uvádza, že na rozdiel od relativistickej predstavy realizmus zastáva názor, že „,na schématech nezávislá struktura reality existuje a rozhoduje o tom, které popisy vnější reality jsou správné“ (Marvan 2014, 38). 
disciplína, a preto je neprijatel'né uspokojit' sa s pluralitou výkladov a neponúknut' vhodný rámec na posúdenie historických výkladov (Kuukkanen 2015, 148). Podla Kuukkanena možno urobit' výber, a práve jeho koncepcia histórie má poskytnút' pomyselný návod.

Kuukkanen sa nazdáva, že historické práce v podstate predkladajú argumenty v prospech zhrňujúcich téz. Sú to preto racionálne a argumentačne podložené práce. Na jednej strane, ako vyplýva z narativistického postrehu, historici formulujú syntetizujúce výklady či tézy za použitia pojmov vytvorených historikmi . Na druhej strane, toto nás nemá doviest' k pochybnostiam o historickom poznaní. Ked'že podl'a Kuukkanena historická práca je racionálna aktivita, v histórii možno pokročit' v poznávaní a vo výbere spomedzi viacerých alternatívnych návrhov či téz. Každé historické dielo má podla neho takzvanú epistemickú, rétorickú a diskurzívnu dimenziu. A pri skúmaní každej z nich možno dané dielo posúdit’ a vybrat tú najlepšiu argumentáciu a tézu (Kuukkanen 2015, kap. 9). ${ }^{7}$

Ako uvedené súvisí s diskusiou o relativizme? Pre správne prepojenie treba vyššie uvedené názory Kuukkanena zasadit' do jeho nonreprezentacionalizmu $(\mathrm{Ku}-$ ukkanen 2013; Kuukkanen 2015, kap. 4). Kuukkanen sa kriticky vymedzuje voči reprezentacionalizmu a svoje názory spája s nonreprezentacionalizmom. Prvé stanovisko sa na historické práce pozerá ako na opisy, zachytenia či reprezentácie nejakej vopred danej predlohy. Druhé stanovisko, naopak, takúto predstavu odmieta a presadzuje iný výklad histórie: „Nonreprezentacionalistický návrh tejto knihy znie, že historiografia je o zdôvodňovaní určitých téz a hlavným prínosom historických prác je poskytnutie neformálnej argumentácie $\mathrm{v}$ prospech alebo neprospech danej tézy“ (Kuukkanen 2015, 66). Kuukkanen sa teda chce rozlúčit's predstavou, podl'a ktorej ciel'om historického diela je čo najvernejšie zobrazit' minulé dianie. Ak niekto pristupuje $\mathrm{k}$ histórii cez túto optiku, samozrejme, že sa musí venovat' otázkam, ako dosiahnut' čo najvernejšie, objektívne či pravdivé zachytenie minulosti. Ak sa však od tejto optiky oslobodíme, o čo sa usiluje práve Kuukkanen, uvedené pochybnosti sa strácajú. A ked’že históriu uchopuje prioritne ako disciplínu, v ktorej historici formulujú tézy a argumentujú v ich prospech (príkladom môže byt' téza „Slovenské povstanie bolo oprávneným ozbrojeným vystúpením za práva Slovákov“, alebo téza „Slovenské povstanie bolo reakčným bojom po boku konzervatívnej Viedne proti pokrokovej revolúcii v Uhorsku“), do popredia sa dostávajú iné problémy. Napríklad ako posúdit' argumentáciu v historických dielach.

\footnotetext{
${ }^{7}$ Pre tento text nie je podstatné do detailov priblížit' jeho koncepciu, ako racionálna diskusia $\mathrm{v}$ histórii vyzerá a ako sa vyberá spomedzi viacerých výkladov za použitia kritérií na posúdenie epistemickej, rétorickej a diskurzívnej dimenzie. Len poznamenávam, že jeho práca (Kuukkanen 2015) tieto záležitosti detailne rozoberá.
} 


\section{Prekonávanie relativizmu}

Roth aj Kuukkanen dost' zásadne menia pohl’ad na historickú disciplínu. Paradigmu histórie reprezentujúcej minulé dianie nahrádzajú návrhmi, v rámci ktorých sa na históriu máme pozriet' z inej perspektívy. Podl'a Rotha sa na ňu treba pozerat' ako na aktivitu, ktorej výstupy nie sú určované akousi vopred danou minulost'ou, ale sú skôr rámcované špecifickou praxou a konkrétnymi krokmi historikov. A práve tieto záležitosti sa majú dostat' do centra záujmu konkrétnych prípadových štúdií. Pre Kuukkanena je história primárne oblast'ou, kde sa argumentuje v prospech syntetizujúcich téz. Ako to lakonicky vyjadruje: „Domnievam sa, že historik je kritický diskutér (critical reasoner)“ (Kuukkanen 2015, 67). Takže historické diela už nie sú reprezentácie, ktoré by mali čo najvernejšie zobrazovat' predlohu, respektíve korešpondovat' s minulost'ou. Pri oboch autoroch je evidentný odklon od takéhoto jednoduchého reprezentacionalizmu. Historici síce podl'a oboch autorov vychádzajú z prameňov - kritická práca s prameňmi, na rozdiel od vymýšl’ania a fabulovania, je súčast'ou historikovej praxe, remesla histórie - avšak nie sú zobrazovači vopred hotovej predlohy.

Prečo je v ich prípade dôležité zdôraznit' odklon od rámca reprezentácie či korešpondencie? Zásadne to mení výklad plurality v histórii. Obaja autori akceptujú, že historici predkladajú rôzne historické diela o tom istom období. Lenže pre Rotha to bude dôsledok odlišných praktických krokov (odlišné štúdium, práca v iných paradigmách či historických školách a pod.) a pre Kuukkanena výsledok odlišných argumentačných stratégií a líšiacich sa syntetizujúcich téz. Ked’že ani jeden z nich sa nepohybuje v úvahách, ktoré určuje paradigma korešpondencie či reprezentacionalizmu, ani jeden z nich nebude vykladat' pluralitu diel ako výsledok použitia rôznych pojmových schém či interpretačných rámcov na rovnaké dáta či rovnaký empirický obsah.

Ako upozorn̆uje Donald Davidson vo svojej slávnej stati proti myšlienke pojmovej schémy, práve dualizmus „schémy a obsahu, organizujúceho systému a niečoho, čo má byt’ organizované“ (Davidson 1997, 121) podporuje pojmový relativizmus. ${ }^{8} \mathrm{Na}$ chvílu predpokladajme, že kantovský dualistický výklad Whitovho narativizmu je správny. Práve dualizmus obsahu a formy, zdá sa, objasňuje, prečo sa v histórii relatívne bežne vyskytujú alternatívne, ale porovnatel’ne presvedčivé výklady rovnakých udalostí. Jednoduchá úvaha znie: rôzne formy (pojmové schémy, uhly pohl'adov, ideologické prístupy) sa aplikujú na rovnaký obsah (dáta, minulé udalosti, pramene), a preto historici prichádzajú s rôznymi výkladmi. Preto disponujeme slovenským, mad’arským i marxistickým výkladom Slovenského povstania. Treba pritom zdôraznit',

${ }^{8}$ Pre detailný kritický rozbor Davidsonových názorov v tejto otázke odporúčam siahnut’ po práci (Marvan 2014, kap. II). 
že práve táto pluralita, založená na rozlíšení formy a obsahu, vedie $\mathrm{k}$ tomu, že narativisti sú obviňovaní z relativizmu.

Čo sa však stane, ked' sa rozlíšeniu medzi obsahom a formou vyhneme? „Na základe dogmy dualizmu schémy a reality dostávame pojmovú relativitu a pravdu, ktorá je vo vzt'ahu $\mathrm{k}$ schéme. Bez tejto dogmy hádžeme takýto druh relativity cez palubu“ (Davidson 1997, 133). Ak sa dualizmu vzdáme, pojmový relativizmus sa rozpadá, pretože sa vytratia nesúmeratel'né pojmové schémy, nekompatibilné teórie, nepreložitel'né jazyky, jednoducho alternatívne formy údajne aplikované na ten istý obsah. Ked’že relativizmus narativizmu bol postavený na dištinkcii medzi obsahom a formou, prekonaním tohto dualizmu sa vyhýbame pojmovému relativizmu. Presne to svojím špecifickým nonreprezentacionalistickým prístupom robia Roth a Kuukkanen. Nehlásia $\mathrm{sa}^{9} \mathrm{k}$ dištinkcii, ktorá je pilierom relativizmu, a tak sa mu vyhýbajú. ${ }^{10}$

Po upustení od problematického dualizmu sa mení i výklad príkladu o Slovenskom povstaní. Nasledujúc názory Rotha a Kuukkanena sú rôzne interpretácie Slovenského povstania výsledkom rôznych praktických krokov historikov (krokov, ktoré sú určené rôznym vzdelaním, preferenciami a pod.), respektíve výsledkom odlišnej argumentácie. Už tu nejde o to, že by sa nejaký spoločný nesformovaný obsah štruktúroval alternatívnymi pojmovými schémami. Otázka organizovania obsahu a porovnávania výsledného historického výkladu s minulou predlohou jednoducho u týchto autorov nevzniká.

\section{Záver}

V centre pozornosti tejto práce bola skutočnost', že v histórii sa stretávame $\mathrm{s}$ viacerými alternatívnymi či súperiacimi historickými výkladmi tej istej časti minulosti. Túto pluralitu víta a vysvetl'uje narativizmus, ktorý je niektorými kritikmi považovaný za relativistickú doktrínu. Napriek tomu, že dvaja súčasní filozofi histórie, Paul Roth a Jouni-Matti Kuukkanen, otvorene nadväzujú na narativizmus, zmienenému relativizmu sa vyhýbajú. Ako som sa pokúsil vo svojej interpretácii ukázat', je to vd’aka

\footnotetext{
${ }^{9}$ Pre sprehl'adnenie a odlíšenie toho, čo sa nachádza explicitne v dielach Rotha a Kuukkanena a čo ponúkam v rámci môjho výkladu v tomto príspevku, si dovolím uviest', že Kuukkanen otvorene zastáva nonreprezentacionalizmus. Aj ked' sám Roth o nonreprezentacionalizme nehovorí, jeho pozíciu tak možno interpretovat'. Tiež chcem upozornit', že predstavenie oboch koncepcií ako prekonávajúcich dualizmus a z toho vyplývajúci pojmový relativizmus sa nenachádza v ich dielach. Roth ani Kuukkanen takto svoje pozície neprezentujú; ide tu o môj výklad ich koncepcí́.

${ }^{10}$ Ako ma upozornil recenzent, hoci sa títo autori vyhýbajú pojmovému relativizmu, kritik sa môže snažit' ukázat', že ich nonreprezentacionalizmus predpokladá kontextuálnost', vzt'ahovost' či relativitu iného druhu. Podl'a Rotha či Kuukkanena môžu byt' totiž rôzne historické práce výsledkom rôznych typov praxe, rôznych druhov konsenzu, aplikácie rôznych argumentačných stratégií a pod. $\mathrm{V}$ tomto prípade však ide o iný druh situácie, ako to bolo pri pojmovom relativizme, pretože tu nejde o aplikovanie rôznych pojmových schém (foriem) na akýsi spoločný nesformovaný obsah.
} 
tomu, že sa vyhýbajú dualizmu obsahu a formy, ktorý je charakteristický pre pojmový relativizmus. Práve ich zásadne odlišný prístup k historickým dielam - nepozerajú sa na historické práce ani ako na reprezentácie minulosti, ani ako na výsledky aplikácie rôznych schém na rovnaký obsah - vedie k tomu, že neuviaznu v dualistickej pasci.

\section{Literatúra}

ANKERSMIT, F. (2009a): Obrat k jazyku: literárna teória a teória histórie. In: Kožiak, R. - Šuch, J. - Zeleňák, E. (eds.): Kapitoly zo súčasnej filozofie dejín. Bratislava: Chronos, 182-228.

ANKERSMIT, F. (2009b): Šest' téz o naratívnej filozofii histórie. In: Kožiak, R. - Šuch, J. - Zeleňák, E. (eds.): Kapitoly zo súčasnej filozofie dejín. Bratislava: Chronos, $171-181$.

BAGHRAMIAN, M., CARTER, J. A. (2020): Relativism. In: Zalta, E. N. (ed.): The Stanford Encycplopedia of Philosophy [online]. Dostupné na: https://stanford.library.sydney.edu.au/entries/relativism/ (Navštívené: 5. 10. 2020).

BAGHRAMIAN, M., COLIVA, A. (2020): Relativism. London: Routledge.

BOGHOSSIAN, P. (2006): Fear of Knowledge: Against Relativism and Constructivism. Oxford: Clarendon Press.

BRUBAKER, R., FEISCHMIDT, M. (2012): 1848 v roku 1998: politika spomínania v Mad’arsku, Rumunsku a na Slovensku. In: Macho, P. a kol.: Revolúcia 1848/49 a historická pamät'. Bratislava: Historický ústav SAV, 205 - 244.

ČERNÍN, D. (2019): Historical Antirealism and the Past as a Fictional Model. Organon F, 26 (4), $635-659$.

DANTO, A. C. (1985): Narration and Knowledge. New York: Columbia University Press.

DAVIDSON, D. (1997): K vlastnej myšlienke pojmovej schémy. In: Davidson, D.: Čin, mysel', jazyk. Bratislava: Archa, $112-133$.

DVORSKÝ, J. (2009): Štruktúry rozprávania v historiografii. Naratologická analýza Vespucciho listu Mundus Novus. Forum Historiae, 3 (2). Dostupné na: http://www.forumhistoriae.sk/sites/default/files/dvorsky1.pdf (Navštívené: 1. 1. 2021).

GOLOB, E. O. (1980): The Irony of Nihilism. History and Theory, 19 (4), 55 - 65.

HORSKÝ, J. (2013): Narativistická kritika dějepisectví a rozhraní mezi historiografíi a (př́rodní) vědou a mezi dějepisnou konstrukcí a literární fikcí. Dějiny - teorie - kritika, (1), 126 - 136.

HORSKÝ, J. - ŠUCH, J. (eds.) (2012): Narace a (živá) realita. Praha: Togga.

JANČOVIČ, I. (2010): K problematike narativity a referencie v historiografii a v umeleckej literatúre. Historický časopis, 58 (4), 621 - 632.

KANSTEINER, W. (1993): Hayden White's Critique of the Writing of History. History and Theory, $32(3), 273-295$

KRAUSZ, M. (2010): Mapping Relativisms. In: Krausz, M. (ed.): Relativism: A Contemporary Anthology. New York: Columbia University Press, $13-30$.

KUUKKANEN, J.-M. (2013): Representationalism and Non-representationalism in Historiography. Journal of the Philosophy of History, 7 (3), 453 - 479.

KUUKKANEN, J.-M. (2015): Postnarrativist Philosophy of Historiography. London: Palgrave Macmillan.

LORENZ, Ch. (1998): Can Histories Be True? Narrativism, Positivism, and the „Metaphorical Turn". History and Theory, 37 (3), 309 - 329.

MARVAN, T. (2014): Realismus a relativismus. Praha: Academia.

MINK, L. O. (1987): History and Fiction as Modes of Comprehension. In: Fay, B. - Golob, E. O. Vann, R. T. (eds.): Historical Understanding. Ithaca: Cornell University Press, $42-60$.

MINK, L. O. (2009) Naratívna forma ako kognitívny nástroj. In: Kožiak, R. - Šuch, J. - Zeleňák, E. (eds.): Kapitoly zo súčasnej filozofie dejín. Bratislava: Chronos, 64 - 83. 
ROTH, P. A. (1988): Narrative Explanations: The Case of History. History and Theory, 27 (1), 1 - 13. ROTH, P. A. (2012): The Pasts. History and Theory, 51 (3), 313 - 339.

ROTH, P. A. (2017): Philosophy of History. In: McIntyre, L. - Rosenberg, A. (eds.): The Routledge Companion to Philosophy of Social Science. New York: Routledge, $397-407$.

ROTH, P. A. (2020): The Philosophical Structure of Historical Explanation. Evanston, Ill.: Northwestern University Press.

SEARLE, J. R. (1995): The Construction of Social Reality. New York: The Free Press.

SIMON, Z. B., KUUKKANEN, J.-M. (2015): Introduction: Assessing Narrativism. History and Theory, 54 (2), $153-161$.

ŠKVARNA, D. (2012): Obraz rokov 1848/49 v slovenskej kultúre (od polovice 19. storočia po súčasnost'). In: Macho, P. a kol.: Revolúcia 1848/49 a historická pamät'. Bratislava: Historický ústav SAV, $37-56$.

ŠUCH, J. (2010): Naratívny konštruktivizmus Haydena Whita a Franka Ankersmita. Ostrava: Ostravská univerzita v Ostravě, Filozofická fakulta.

UDALCOV, I. I. (1951): Slovanské národy Rakúskej ríše v revolučnom hnutí r. 1848 vo výskumoch sovietskych historikov. In: Holotík, L. (ed.): Revolučné dedičstvo rokov 1848 - 1849. Bratislava: Slovenská akadémia vied a umení, $74-85$.

WHITE, H. (2011): Metahistorie: Historická imaginace v Evropě devatenáctého století. Brno: Host.

WHITE, H. (2009): Historický text ako literárny artefakt. In: Kožiak, R. - Šuch, J. - Zeleňák, E. (eds.): Kapitoly zo súčasnej filozofie dejín. Bratislava: Chronos, 134 - 153.

ZELENÁK, E. (2011): Konštruktivizmus a pluralita v histórii. Ružomberok: Verbum - vydavatel'stvo Katolíckej univerzity v Ružomberku.

Práca vznikla v rámci projektu VEGA č. 1/0640/19 s názvom Pojmový relativizmus v súčasnej filozofii: vymedzenie, limity a problémy.

Eugen Zeleňák

Katolícka univerzita v Ružomberku

Filozofická fakulta, Katedra filozofie

Hrabovská cesta 1B

03401 Ružomberok

Slovenská republika

e-mail: eugen.zelenak@ku.sk

ORCID ID: https://orcid.org/0000-0002-0576-4080 